\title{
Epilepsy Research in India: A Scientometric Analysis of Publications Output during 2002-11
}

\author{
Brij M.Gupta ${ }^{1}$ and Adarsh Bala²
}

${ }^{1}$ National Institute of Science, Technology \& Development Studies, New Delhi 110 012, ${ }^{2}$ Government Medical College \& Hospital, Sector 32, Chandigarh, INDIA ABSTRACT

This study analyses the research output of India in epilepsy research during 2002-11 on several parameters including the growth, rank and global publications share, citation impact, share of international collaborative papers, contribution of major collaborative partner countries, contribution of various subject-fields, contribution and impact of most productive institutions and authors, media of communication and characteristics of high cited papers. The Scopus Citation Database has been used to retrieve the data for 10 years (2002-11) by searching the keywords "epilepsy research" in the combined Title, Abstract and Keywords fields. Among the top 20 most productive countries in epilepsy research, India ranks at $11^{\text {th }}$ position (with 1550 papers) with a global publication share of $2.88 \%$ and an annual average publication growth rate of $15.31 \%$ during 2002-11. Its global publication share has increased over the years, rising from $2.06 \%$ in 2002 to $4.65 \%$ during 2011 . Its citation impact per paper was 2.77 during 2002-11, which decreased from 3.48 during 2002-06 to 2.41 during 2007-11. Its international collaborative publications share was $12.32 \%$ during $2002-11$, which decreased from $12.45 \%$ during $2002-06$ to $12.26 \%$ during $2007-11$. Concludes that India needs to increase both the quantity and quality of research and also the need to share research data and stimulate national and international collaborative research, which will increase both the quantity and quality of research in epilepsy. There is a need to develop a national program on epilepsy as a part of national health plan, besides suggesting the funding agencies to establish a more ambitious funding program into the causes, prevention, cure and care of epilepsy. There is a need to build capacity at all levels of human resources for the management of epilepsy.

KEYWORDS: Epilepsy research, Publications, Scientometrics.

Corresponding Author: Brij M.Gupta, Address: National Institute of Science, Technology \& Development Studies, New Delhi 110 012, INDIA, Tel: +91-9888378275, Email: bmgupta1@gmail.com

doi : $10.5214 /$ ans.0972.7531.200209

\section{Introduction}

Epilepsy was one of the first brain disorders to be described. It was mentioned in ancient Babylon more than 3,000 years ago. The strange behavior caused by some seizures has contributed through the ages to many superstitions and prejudices. The word epilepsy is derived from the Greek word for "attack." However, in 400 B.C., the early physician Hippocrates suggested that epilepsy was a disorder of the brain and we now know that he was right. ${ }^{1}$

The brain consists of millions of nerve cells, or neurons, and their supporting structure. Each neuron maintains itself in an electrically charged state. It receives electrical signals from other neurons, and passes them on to others. What actually happens is that a tiny quantity of a special neurotransmitter substance is released from the terminals of one neuron. This chemical excites an electrical response in the neuron next in the chain, and so the signal moves onward. All the functions of the brain, including feeling, seeing, thinking and moving muscles depend on electrical signals being passed from one neuron to the next, the message being modified as required. The normal brain is constantly generating electrical rhythms in an orderly way. In epilepsy this order is disrupted by some neuron discharging signals inappropriately. There may be a kind of brief electri- cal "storm" arising from neurons that are inherently unstable because of a genetic defect (as in the various types of inherited epilepsy), or from neurons made unstable by metabolic abnormalities, such as low blood glucose, or alcohol. Alternatively, the abnormal discharge may come from a localised area of the brain (this is the situation in patients with epilepsy caused by head injury or brain tumour). ${ }^{2}$

The best available classification of seizures is that proposed by the International League Against Epilepsy ("seizure" is an alternative term for "epileptic attack"). It starts by dividing seizures into partial seizures, where the abnormal electrical discharge originates from one specific area of the brain and generalised seizures, where the whole brain is involved. What makes it a little confusing is that a partial seizure may occasionally go on to become generalised, if the epileptic discharge originating in one area of the brain is strong enough to then spread to the whole brain. However, even if the situation of a partial seizure progressing to become generalised, with complete loss of consciousness, convulsions, etc., the initial symptoms will be prominent, and will distinguish it from other forms of generalised epilepsy, where the whole brain is involved from the outset. ${ }^{2}$

The incidence and prevalence of epilepsy may vary widely because of their different causes. Parasitic, viral and bacterial infections have been suggested as important factors in the cause of epilepsy in developing countries, also infections, brain damage occurring at birth or in accidents, or other brain trauma. Some of these factors may be reduced in developing countries by improved prevention and treatment. In the affluent countries, reduction of strokes and brain tumors may lessen the incidence of epilepsy. Although it has a minor role, genetic counseling can also help to prevent certain types of epilepsy. ${ }^{3}$

Epilepsy affects about 50 million people throughout the world and is especially common in childhood and in elderly people. Epilepsy affects not only the individual, but also has consequences for the family and the rest of society. A minimum of 250 million people will experience at least one seizure in their lifetime and at least 2.4 million new cases of epilepsy occur each year. The incidence of epilepsy is generally taken to be between 40 and 70 per 100,000 people per year in industrialized countries, with estimates of 100 - 190 per 100,000 people per year in developing countries. The prevalence is between 5 and 40 per 1000 persons. $^{3}$ It is estimated than there are more than 10 million persons with epilepsy (PWE) in India. Its prevalence is about $1 \%$ of our population, this being higher in the rural $(1.9 \%)$ as compared with the urban population $(0.6 \%){ }^{4}$ 
The incidence and prevalence of epilepsy may vary widely because of their different causes. Parasitic, viral and bacterial infections have been suggested as important factors in the cause of epilepsy in developing countries, also infections, brain damage occurring at birth or in accidents, or other brain trauma. Some of these factors may be reduced in developing countries by improved prevention and treatment. In the affluent countries, reduction of strokes and brain tumors may lessen the incidence of epilepsy. Although it has a minor role, genetic counseling can also help to prevent certain types of epilepsy. ${ }^{3}$

Till today, no quantitative study at the global or country level on epilepsy research literature has been carried out in the past. However, few Indian scholars and the present author in collaboration with other scholars has carried out similar studies in Indian context on other diseases such as diabetes, ${ }^{5-7}$ tuberculosis, ${ }^{8,9}$ malaria, ${ }^{10,11}$ AIDS/HIV, ${ }^{12}$ cancer, ${ }^{13}$ asthma, ${ }^{14}$ typhoid $^{15}$ and heredity blood disorder ${ }^{16}$.

\section{Objectives}

The main objective of this study is to analyze the research output of India in epilepsy research in national and global contexts, as reflected in its publications output during 2002-11. The study has the following objectives: (i) To study the Indian research output, its growth, rank and global publications share and citation impact, (ii) To study the patterns of international collaboration and identification of major collaborators, (iii) To study the contribution by sub-fields, (iv) To study the publications productivity and impact of leading institutions and authors of India and (v) To study the characteristics of highly cited papers.

\section{Methodologies and Source of Data}

This study used Scopus International Database [http://www.scopus.com/search/] to extract relevant data on Epilepsy research in India and other most productive countries for the 10 years (2002-11).

For search world data on epilepsy research, the following string was used in advanced search

TITLE-ABS-KEY(epilepsy) AND PUBYEAR > 2001 AND PUBYEAR $<2012$

For search data on India, an advanced search strategy involving "Epilepsy" as the keyword in "Title, Abstract and Keywords field" together with "India" in the "affiliation field" and limiting the data range to 2002 to 2011 was used, resulting in downloading of 1550 records on India related to epilepsy. The actual search strategy used in advanced search for downloading data on India is given below:

(TITLE-ABS-KEY(Epilepsy) AND AFFIL(india)) AND PUBYEAR > 2001 AND PUBYEAR $<2012$

For downloading Indian data on various subjects, the above strategy was limited to individual subjects, such as the following string in advanced search for search data on medicine.

(TITLE-ABS-KEY(epilepsy) AND AFFIL(india)) AND PUBYEAR > 2001 AND PUBYEAR < 2012 AND (LIMITTO(SUBJAREA,"medi" ) ).

For searching data on top most productive countries, string similar to Indian string was used such as the following"

(TITLE-ABS-KEY(epilepsy) AND AFFIL(germany)) AND PUBYEAR > 2001 AND PUBYEAR $<2012$

For citations data, three years, two years, one year and zero year citation windows have been used for computing average citations per paper in epilepsy research during 2002-08, 2009, 2010 and 2011. For example, for papers published in 2002, citation window is three years from 200205. For papers published in 2009, citation window is two years from 2009-2011, and for papers published in 2010 citation window is one year 2010-11. For identifying India's international collaborative papers, a separate search strategy was prepared. For analyzing significant institutions, authors and journals, separate search strategies were developed, which later combined with the main string lead to the generation of the desired output. For generating high-cited papers, the main string was first run. Then, the tag "citation to" was ticked, to rearrange the entire output in the decreasing order of citations received by each paper with most high-cited papers at the top. Then the high-cited papers are marked and downloaded for analyses.

\section{Analysis}

\section{Global Publication Share \& Rank}

The global publication share of the top 20 most productive countries in epilepsy research varies from $1.06 \%$ to $25.58 \%$ during 2002-11. The United States tops the list, with a publication share of $25.58 \%$ during 2002-11. The United Kingdom ranks second (with $8.67 \%$ share), followed by Germany $(7.81 \%$ share), Italy $(7.52 \%$ share), France, Japan, Canada, China, Spain and Netherlands (with publications share ranging from $3.01 \%$ to $5.68 \%$ ). India, Brazil, Australia and Turkey ranks at $11^{\text {th }}$ to $14^{\text {th }}$ positions (their global publications share ranging from $2.25 \%$ to $2.88 \%$ ). The countries that fall between $15^{\text {th }}$ and $20^{\text {th }}$ positions are Switzerland, Belgium, Sweden, South Korea, Poland and Austria with their global publications share ranging from $1.05 \%$ to $1.99 \%$ (Table 1 ).

The developed countries showing increase in their publications share are United States by $2.11 \%$, followed by Turkey $(1.04 \%)$, Italy $(0.70 \%)$, Australia $(0.69 \%)$, Poland $(0.66 \%)$, Sweden $(0.19 \%)$, Netherlands $(0.0 .17 \%)$, Belgium $(0.17 \%)$, Switzerland $(0.03 \%)$ and Austria $(0.01 \%)$ from the year 2002 to the year 2011. In contrast, the developed countries showing decrease in their publications share during the same period are France by $1.29 \%$, Germany (1.17\%), Spain $(1.02 \%)$, U.K. $(0.99 \%)$, Japan $(0.88 \%)$ and Canada $(0.01 \%)$. All developing countries among the top 20 countries, on the other hand, have shown rise in their publications share in epilepsy research: China by $3.48 \%$, followed by India (2.58\%), South Korea $(0.87 \%)$ and Brazil $(0.55 \%)$ from the year 2002 to the year 2011 (Table 1).

India ranks at $11^{\text {th }}$ position among the top 20 most productive countries in epilepsy research with its global publications share of 2.88\% during 2002-11. China, Brazil and South Korea ranked at $8^{\text {th }}, 12^{\text {th }}$ and $18^{\text {th }}$ positions, with global publications share of $3.56 \%, 2.86 \%$ and $1.19 \%$, respectively during $2002-11$. India's global publications share increased from $2.06 \%$ to $4.65 \%$ from the year 2002 to the year 2011. China, Brazil and South Korea's global publications share increased from $1.75 \%$ to $5.23 \%, 2.29 \%$ to $2.84 \%$ and $0.79 \%$ to $1.19 \%$ from the year 2002 to the year 2011 (Table 1).

Considering the quality of papers published by these productive countries in terms of average citation per paper which varies from 3.53 to 12.56 during 2002-11. The highest citation impact is registered by Sweden with 12.07 citations per paper, followed by Netherlands (9.88), U.K (9.52), Australia (9.23), Belgium (9.18), Switzerland (8.82), Canada (8.76), Germany (8.19), Austria (7.75), USA (7.48), Italy (6.88), France (6.88), South Korea (5.47), Spain (5.09), Japan (4.38), Poland 
Table 1: Publications Output, Share and Rank of Top 20 Countries in Epilepsy Research, 2002-11

\begin{tabular}{|c|c|c|c|c|c|c|c|c|c|}
\hline \multirow[t]{2}{*}{ S. No. } & \multirow[t]{2}{*}{ Country } & \multicolumn{3}{|c|}{ Number of Papers } & \multicolumn{3}{|c|}{ Share of Papers } & \multirow{2}{*}{$\begin{array}{c}\begin{array}{c}\text { Total } \\
\text { Citations }\end{array} \\
2002-11\end{array}$} & \multirow{2}{*}{$\begin{array}{c}\text { ACPP } \\
2002-11\end{array}$} \\
\hline & & 2002 & 2011 & $2002-11$ & 2002 & 2011 & $2002-11$ & & \\
\hline 1. & USA & 1086 & 1749 & 13755 & 24.62 & 26.73 & 25.58 & 102845 & 7.48 \\
\hline 2. & UK & 422 & 561 & 4662 & 9.57 & 8.57 & 8.67 & 44386 & 9.52 \\
\hline 3. & Germany & 376 & 481 & 4198 & 8.52 & 7.35 & 7.81 & 34398 & 8.19 \\
\hline 4. & Italy & 302 & 494 & 4043 & 6.85 & 7.55 & 7.52 & 27826 & 6.88 \\
\hline 5. & France & 243 & 276 & 3055 & 5.51 & 4.22 & 5.68 & 21024 & 6.88 \\
\hline 6. & Japan & 249 & 312 & 2459 & 5.64 & 4.77 & 4.57 & 10770 & 4.38 \\
\hline 7. & Canada & 183 & 271 & 2408 & 4.15 & 4.14 & 4.48 & 21106 & 8.76 \\
\hline 8. & China & 77 & 342 & 1917 & 1.75 & 5.23 & 3.56 & 5188 & 2.71 \\
\hline 9. & Spain & 171 & 187 & 1663 & 3.88 & 2.86 & 3.09 & 8466 & 5.09 \\
\hline 10. & Netherlands & 117 & 185 & 1617 & 2.65 & 2.83 & 3.01 & 15980 & 9.88 \\
\hline 11. & India & 91 & 304 & 1550 & 2.06 & 4.65 & 2.88 & 4295 & 2.77 \\
\hline 12. & Brazil & 101 & 186 & 1538 & 2.29 & 2.84 & 2.86 & 6265 & 4.07 \\
\hline 13. & Australia & 84 & 170 & 1296 & 1.90 & 2.60 & 2.41 & 11960 & 9.23 \\
\hline 14. & Turkey & 62 & 160 & 1209 & 1.41 & 2.45 & 2.25 & 4061 & 3.36 \\
\hline 15. & Switzerland & 79 & 119 & 1068 & 1.79 & 1.82 & 1.99 & 9416 & 8.82 \\
\hline 16. & Belgium & 54 & 91 & 860 & 1.22 & 1.39 & 1.60 & 7895 & 9.18 \\
\hline 17. & Sweden & 49 & 85 & 670 & 1.11 & 1.30 & 1.25 & 8084 & 12.07 \\
\hline 18. & South Korea & 35 & 109 & 639 & 0.79 & 1.67 & 1.19 & 3495 & 5.47 \\
\hline 19. & Poland & 35 & 95 & 598 & 0.79 & 1.45 & 1.11 & 2582 & 4.32 \\
\hline 20. & Austria & 46 & 69 & 570 & 1.04 & 1.05 & 1.06 & 4416 & 7.75 \\
\hline & World & 4411 & 6543 & 53778 & & & & & \\
\hline
\end{tabular}

$\mathrm{ACPP}=$ Average Citation Per Paper

(4.32), Brazil (4.07), Turkey (3.36), India (2.77) and China (2.71) (Table 1)

\section{India's Publication Output in Epilepsy Research}

India's cumulative publication output in epilepsy research consisted of 1550 papers during 2002-11, with an average number of 155 papers per year and an annual average growth rate of $15.31 \%$. The cumulative publications output of India in epilepsy research increased from 522 papers during 2002-06 to 1028 papers during 2007-11, witnessing a growth of $96.93 \%$ (Table 2). In terms of impact and citation quality, the average citation per paper registered by India's publication output was 2.77 during 2002-11. The average citation per paper of cumulative publications in epilepsy research of India has decreased from 3.48 during 2002-06 to 2.41 during 2007-11 (Table 2).

\section{International Collaboration in India's Publication Output}

The total number of Indian papers involving international collaboration during $2002-11$ is 191 , accounting for $12.32 \%$ share in the cumulative publications output of India in epilepsy research. India witnessed a decrease in the share of its international collaborative papers from $12.45 \%$ during $2002-06$ to $12.26 \%$ during 2007-11 in epilepsy research (Table 2)

Among the major international collaborators (59 countries), 15 countries have published 4 or more collaborative papers with India during 2002-11 (Table 3). United States was the major collaborating partner of India during 2002-11 accounting for $41.88 \%$ of collaborative publications, followed by United Kingdom (with $24.61 \%$ share), Japan, Australia, Canada, Germany, Switzerland, Italy and Belgium (varying its publication share from $4.19 \%$ to $7.85 \%)$, Malaysia, Brazil, Spain, Singapore, France and Austria (varying its publication share from $2.09 \%$ to $3.66 \%$ ) during 2002-2011.

Of these top 15 international collaborative countries, India's collaborative linkages has decreased with two countries with largest decrease in USA by $15.80 \%$, followed by Switzerland (3.72\%) from 2002-06 to 2007-11. India's collaborative linkages have increased with 13 countries with maximum increase of $6.98 \%$ with UK, followed by Germany (4.07\%), Belgium $(4.02 \%)$, France $(3.97 \%)$, Malaysia $(3.22 \%)$, Austria (3.17\%), Italy (2.48\%), Brazil $(2.43 \%)$, Spain $(2.43 \%)$, Australia $(1.78 \%)$, Canada $(1.78 \%)$, Singapore (1.64\%) and Japan 90.24\%) from 2002-06 to 2007-11 (Table 3).

\section{Indian Epilepsy Research Output in Context of Different Subjects}

India's publication output in Epilepsy research during 2002-11 has been published in context of 8 subjects (as reflected in database classification based on journal subject content), with highest publications output coming from medicine (1150 papers and $74.19 \%$ publications share), followed by neurosciences (497 papers and $32.06 \%$ publications share), pharmacology, toxicology \& pharmaceutics (301 papers and $19.42 \%$ publications share), biochemistry, genetics \& molecular biology (179 papers and $11.55 \%$ publications share), psychiatry and psychology (48 papers and $3.10 \%$ publications share), chemistry (42 papers and $2.65 \%$ publications share), immunology and microbiology (40 papers and $2.58 \%$ publications share) 
Table 2: Growth \& International Collaboration Share of Indian Epilepsy Publications, 2002-11

\begin{tabular}{|c|c|c|c|c|c|}
\hline Period & TP & TC & ACPP & ICP & \%ICP \\
\hline 2002 & 91 & 185 & 2.03 & 5 & 5.49 \\
\hline 2003 & 104 & 313 & 3.01 & 13 & 12.50 \\
\hline 2004 & 90 & 357 & 3.97 & 13 & 14.44 \\
\hline 2005 & 111 & 441 & 3.97 & 23 & 20.72 \\
\hline 2006 & 126 & 522 & 4.14 & 11 & 8.73 \\
\hline 2007 & 146 & 833 & 5.71 & 22 & 15.07 \\
\hline 2008 & 175 & 665 & 3.80 & 27 & 15.43 \\
\hline 2009 & 171 & 590 & 3.45 & 23 & 13.45 \\
\hline 2010 & 232 & 309 & 1.33 & 21 & 9.05 \\
\hline 2011 & 304 & 80 & 0.26 & 33 & 10.86 \\
\hline $2001-06$ & 522 & 1818 & 3.48 & 65 & 12.45 \\
\hline $2007-11$ & 1028 & 2477 & 2.41 & 126 & 12.26 \\
\hline $2002-11$ & 1550 & 4295 & 2.77 & 191 & 12.32 \\
\hline
\end{tabular}

$\mathrm{TP}=$ Total Papers; $\mathrm{TC}=$ Total Citations; $\mathrm{CPP}=$ Average Citations per Paper; $\mathrm{ICP}=$ International Collaborative Papers

Table 3: Contribution of Major Collaborative Partners of India in Epilepsy Research during 2002-11

\begin{tabular}{|c|c|c|c|c|c|c|c|}
\hline \multirow[t]{2}{*}{ S. No. } & \multirow{2}{*}{$\begin{array}{l}\text { Names of Collaborat- } \\
\text { ing Countries with } \\
\text { India }\end{array}$} & \multicolumn{3}{|c|}{ ICP } & \multicolumn{3}{|c|}{$\%$ ICP } \\
\hline & & $2002-06$ & 2007-11 & 2002-11 & $2002-06$ & 2007-11 & 2002-11 \\
\hline 1. & USA & 34 & 46 & 80 & 52.31 & 36.51 & 41.88 \\
\hline 2. & UK & 13 & 34 & 47 & 20.00 & 26.98 & 24.61 \\
\hline 3. & Japan & 5 & 10 & 15 & 7.69 & 7.94 & 7.85 \\
\hline 4. & Australia & 4 & 10 & 14 & 6.15 & 7.94 & 7.33 \\
\hline 5. & Canada & 4 & 10 & 14 & 6.15 & 7.94 & 7.33 \\
\hline 6. & Germany & 2 & 9 & 11 & 3.08 & 7.14 & 5.76 \\
\hline 7. & Switzerland & 5 & 5 & 10 & 7.69 & 3.97 & 5.24 \\
\hline 8. & Italy & 2 & 7 & 9 & 3.08 & 5.56 & 4.71 \\
\hline 9. & Belgium & 1 & 7 & 8 & 1.54 & 5.56 & 4.19 \\
\hline 10. & Malaysia & 1 & 6 & 7 & 1.54 & 4.76 & 3.66 \\
\hline 11. & Brazil & 1 & 5 & 6 & 1.54 & 3.97 & 3.14 \\
\hline 12. & Spain & 1 & 5 & 6 & 1.54 & 3.97 & 3.14 \\
\hline 13. & Singapore & 1 & 4 & 5 & 1.54 & 3.17 & 2.62 \\
\hline 14. & France & 0 & 5 & 5 & 0.00 & 3.97 & 2.62 \\
\hline \multirow[t]{2}{*}{15.} & Austria & 0 & 4 & 4 & 0.00 & 3.17 & 2.09 \\
\hline & Total* & 65 & 126 & 191 & & & \\
\hline
\end{tabular}

ICP = International Collaborative Papers

*Total collaborating papers of India. In all collaborating papers of India, there are one or more foreign collaborating countries. As a result, the combined output of 15 foreign collaborating countries listed above in Indian international collaborative output will be more than its total international collaborative papers

and agricultural \& biological sciences ( 32 papers and $2.06 \%$ publications share). On analyzing the quality and citation impact of epilepsy research under different subjects, it was found that agricultural \& biological sciences had scored the highest impact of 5.13 citations per paper), fol- ogy \& pharmaceutics (2.84 citations per paper), and medicine ( 2.53 citations per paper) (Table 4)

Research Profile of Most Productive Indian Institutions in Epilepsy Research

The top 15 most productive Indian institutions involved in epilepsy research have published 16 or more papers each during 2002-11. The publication profiles of these 15 Indian institutions along with their research output, citations received and $\mathrm{h}$-index values are presented in Table 5 . These 15 Indian institutions account for $42.64 \%$ share (661 papers) of the publications output of India with an average output per institution of 44.06. Five Indian institutions have registered higher publications share than the group average. These are All India Institute of Medical Sciences, New Delhi with 133 papers during 2002-11, followed by Sree Chitra Tirunal Institute for Medical Science and Technology, Thiruvanathapuram (122 papers), National Institute of Mental Health \& Neurosciences, Bangalore (71 papers), Postgraduate Institute of Medical Education \&Research, Chandigarh (60 papers) and Sanjay Gandhi Postgraduate Institute of Medical Sciences, Lucknow (51 papers). The average citation per paper registered by the total papers of these 15 Indian institutions is 3.72 on a three year citation window. Six Indian institutions have registered comparative higher impact than the group average. The highest impact of 7.57 citations per paper was scored by the Panjab University, University Institute of Pharmaceutical Sciences, Chandigarh, followed by King Edward Memorial Hospital, Mumbai (5.89 citations per paper), National Institute of Mental Health \& Neurosciences, Bangalore (4.90 citations per paper), Sanjay Gandhi Postgraduate Institute of Medical Sciences, Lucknow (4.22 citations per paper), Dayanand Medical College and Hospital, Ludhiana (4.13) and Chhatrapati Shahuji Maharaj Medical University, Lucknow (4.05). Measuring the performance of these institutions on the basis of $\mathrm{h}$ - index, seven institutions have achieved a higher h-index value than the group average of 9.0. These are Sree Chitra Tirunal Institute for Medical Science and Technology, Thiruvanathapuram and All India Institute of Medical Sciences, New Delhi with h-index of 16 each, followed by Panjab University, University Institute of Pharmaceutical Sciences, Chandigarh, National Institute of Mental Health \& Neurosciences, Bangalore and Sanjay Gandhi Postgraduate 
Table 4: Subject-Wise Break-up of Indian Epilepsy Publications during 2002-11

\begin{tabular}{|l|c|c|c|}
\hline \multirow{2}{*}{ Subject } & \multicolumn{3}{|c|}{ 2002-11 } \\
\cline { 2 - 4 } & TP & TC & ACPP \\
\hline Medicine & 1150 & 2905 & 2.53 \\
\hline Neurosciences & 497 & 1997 & 4.02 \\
\hline Pharmacology, Toxicology \& Pharmaceutics & 301 & 855 & 2.84 \\
\hline Biochemistry, Genetics \& Molecular Biology & 179 & 676 & 3.78 \\
\hline Psychiatry \& Psychology & 48 & 239 & 4.98 \\
\hline Chemistry & 41 & 162 & 3.95 \\
\hline Immunology \& Microbiology & 40 & 114 & 2.85 \\
\hline Agricultural \& Biological Sciences & 32 & 164 & 5.13 \\
\hline Total* & 1550 & & \\
\hline
\end{tabular}

$\mathrm{TP}=$ Total Papers; $\mathrm{TC}=$ Total Citations; $\mathrm{ACPP}=$ Average Citations per Paper;

*Total of India in Epilepsy research. There is some overlapping of literature under different subject fields. As a result, the combined output of India under 7 subject fields will be more than its total research output

Table 5: Productivity \& Impact of Top Fifteen Indian Institutions in Epilepsy Research, 2002-11

\begin{tabular}{|c|c|c|c|c|c|}
\hline S.No & Name & TP & TC & ACPP & H-Index \\
\hline 1 & $\begin{array}{l}\text { All India Institute of Medical Sciences, New } \\
\text { Delhi }\end{array}$ & 133 & 459 & 3.45 & 16 \\
\hline 2 & $\begin{array}{l}\text { Sree Chitra Tirunal Institute for Medical Science } \\
\text { and Technology, Thiruvanathapuram }\end{array}$ & 122 & 425 & 3.48 & 16 \\
\hline 3 & $\begin{array}{l}\text { National Institute of Mental Health \& Neurosci- } \\
\text { ences, Bangalore }\end{array}$ & 71 & 348 & 4.90 & 12 \\
\hline 4 & $\begin{array}{l}\text { Postgraduate Institute of Medical Education } \\
\text { \&Research, Chandigarh }\end{array}$ & 60 & 178 & 2.97 & 11 \\
\hline 5 & $\begin{array}{l}\text { Sanjay Gandhi Postgraduate Institute of Medi- } \\
\text { cal Sciences, Lucknow }\end{array}$ & 51 & 215 & 4.22 & 12 \\
\hline 6 & Christian Medical College \& Hospital, Vellore & 40 & 144 & 3.60 & 10 \\
\hline 7 & Gajra Raja Medical College, Gwalior & 30 & 63 & 2.10 & 5 \\
\hline 8 & Jamia Hamdard, Delhi & 28 & 104 & 3.71 & 8 \\
\hline 9 & $\begin{array}{l}\text { Panjab University, University Institute of Phar- } \\
\text { maceutical Sciences, Chandigarh }\end{array}$ & 21 & 159 & 7.57 & 12 \\
\hline 10 & $\begin{array}{l}\text { Chhatrapati Shahuji Maharaj Medical University, } \\
\text { Lucknow }\end{array}$ & 20 & 81 & 4.05 & 8 \\
\hline 11 & King Edward Memorial Hospital, Mumbai & 19 & 112 & 5.89 & 6 \\
\hline 12 & $\begin{array}{l}\text { Nizam's Institute of Medical Sciences, Hyder- } \\
\text { abad }\end{array}$ & 17 & 49 & 2.88 & 5 \\
\hline 13 & University College of Medical Sciences, Dehi & 17 & 28 & 1.65 & 4 \\
\hline 14 & G.B.Pant Hospital, Delhi & 16 & 27 & 1.69 & 5 \\
\hline 15 & $\begin{array}{l}\text { Dayanand Medical College and Hospital, } \\
\text { Ludhiana }\end{array}$ & 16 & 66 & 4.13 & 5 \\
\hline & Total & 661 & 2458 & 3.72 & 9 \\
\hline & Total of the Country's Output & 1550 & & & \\
\hline & $\begin{array}{l}\text { Share of top } 15 \text { institutions in country's total } \\
\text { output }\end{array}$ & 42.64 & & & \\
\hline
\end{tabular}

TP $=$ Total Papers; $\mathrm{TC}=$ Total Citations; $\mathrm{ACPP}=$ Average Citations Per Paper
Institute of Medical Sciences, Lucknow (12 each), Postgraduate Institute of Medical Education \&Research, Chandigarh (11), Christian Medical College \& Hospital, Vellore (10)(Table 5)

\section{Contributions and Impact of Most Productive Authors in Indian Epilepsy Research}

Fifteen authors have been identified as productive authors who have published 18 or more papers in epilepsy research. These 15 authors together contributed 399 papers with an average of 26.60 papers per author and account for $25.74 \%$ of publications share in output of India during 2002-11. Six authors have published higher number of papers than the group average (28.60). These are: Kurupath Radhakrishnan with 59 papers, followed by S.V. Thomas (35 papers), Harinder Jaseja (30 papers), P. Satishchandra (29 papers), C. Kesavadas (28 papers) and M. Tripathi (28 papers). Considering the quality/impact of papers, these productive authors have received a total of 1579 citations for 399 papers with an average of 3.71 citations per paper. Eight authors have registered higher impact than the average. These are: S.K. Kulkurni with ACPP of 8.0, followed by K. Kalita (5.0), P. Satishchandra (4.83), P.S.Sarma (4.58), U.K..Misra (4.55), S. Sinha (4.09), Kurupath Radhakrishnan (4.02) and S.V. Thomas (3.80). Measuring the performance of these authors on the basis of $h$ - index, seven authors have achieved a higher $h$-index value than the group average of 7.33. These are Kurupath Radhakrishnan wth h-index of 12, S.K. Kulkurni (11), S.V. Thomas, P. Satishchandra and M. Tripathi (9 each), P.S.Sarma and S. Jain (8 each) (Table 6)

\section{Patterns of Research Communication}

The 15 most productive Indian and foreign journals publishing Indian research papers together contributed 217 papers in epilepsy research, which accounts for $35.74 \%$ of the total output of India during 2002-11. The cumulative publications share of these 15 most productive journals showed a decrease in India's publications output from $41.57 \%$ during 2002-06 to $32.78 \%$ during $2007-11$ (Table 7).

\section{High Cited Papers}

India has published 12 high cited papers in Epilepsy research in last 10 years (2002-11) and these have received from 50 to 217 citations per paper. Of these 
Table 6: Productivity \& Impact of Fifteen Most Productive Indian Authors in Epilepsy Research, 2002-11

\begin{tabular}{|c|c|c|c|c|c|c|}
\hline S.No & Name & Address & TP & TC & ACPP & H-Index \\
\hline 1 & $\begin{array}{l}\text { Kurupath } \\
\text { Radhakrishnan }\end{array}$ & $\begin{array}{l}\text { Sree Chitra Tirunal Institute for Medical Science and } \\
\text { Technology, Thiruvanathapuram }\end{array}$ & 59 & 237 & 4.02 & 12 \\
\hline 2 & Harinder Jaseja & Gajra Raja Medical College, Gwalior & 30 & 62 & 2.07 & 5 \\
\hline 3 & S.V. Thomas & $\begin{array}{l}\text { Sree Chitra Tirunal Institute for Medical Science and } \\
\text { Technology, Thiruvanathapuram }\end{array}$ & 35 & 133 & 3.80 & 9 \\
\hline 4 & P. Satishchandra & $\begin{array}{l}\text { National Institute of Mental Health \& Neurosciences, } \\
\text { Bangalore }\end{array}$ & 29 & 140 & 4.83 & 9 \\
\hline 5 & C. Kesavadas & $\begin{array}{l}\text { Sree Chitra Tirunal Institute for Medical Science and } \\
\text { Technology, Thiruvanathapuram }\end{array}$ & 28 & 87 & 3.11 & 7 \\
\hline 6 & M. Tripathi & All India Institute of Medical Sciences, New Delhi & 28 & 104 & 3.71 & 9 \\
\hline 7 & P.S.Sarma & $\begin{array}{l}\text { Sree Chitra Tirunal Institute for Medical Science and } \\
\text { Technology, Thiruvanathapuram }\end{array}$ & 24 & 110 & 4.58 & 8 \\
\hline 8 & S. Jain & All India Institute of Medical Sciences, New Delhi & 23 & 82 & 3.57 & 8 \\
\hline 9 & S. Sinha & $\begin{array}{l}\text { National Institute of Mental Health \& Neurosciences, } \\
\text { Bangalore }\end{array}$ & 22 & 90 & 4.09 & 7 \\
\hline 10 & K. Kalita & $\begin{array}{l}\text { Sanjay Gandhi Postgraduate Institute of Medical Sciences, } \\
\text { Lucknow }\end{array}$ & 22 & 110 & 5.00 & 7 \\
\hline 11 & S. Gulati & All India Institute of Medical Sciences, New Delhi & 22 & 36 & 1.64 & 5 \\
\hline 12 & U.K..Misra & $\begin{array}{l}\text { Sanjay Gandhi Postgraduate Institute of Medical Sciences, } \\
\text { Lucknow }\end{array}$ & 22 & 100 & 4.55 & 7 \\
\hline 13 & S.K. Kulkurni & $\begin{array}{l}\text { Panjab University, University Institute of Pharmaceutical } \\
\text { Sciences, Chandigarh }\end{array}$ & 18 & 144 & 8.00 & 11 \\
\hline 14 & V.Kalra & All India Institute of Medical Sciences, New Delhi & 19 & 40 & 2.11 & 5 \\
\hline \multirow[t]{4}{*}{15} & R. Harikumar & Bannar Amman Institute of Technology, Sathyamangalam & 18 & 4 & 0.22 & 1 \\
\hline & Total & & 399 & 1479 & 3.71 & 7.33 \\
\hline & $\begin{array}{l}\text { Total of the } \\
\text { Country's output }\end{array}$ & & 1550 & & & \\
\hline & $\begin{array}{l}\text { Share of top } 15 \text { authors } \\
\text { in country total }\end{array}$ & & 25.74 & & & \\
\hline
\end{tabular}

TP $=$ Total Papers; $\mathrm{TC}=$ Total Citations; ACPP $=$ Average Citations Per Paper

Table 7: List of Most Productive Journals Publishing Indian Papers in Epilepsy, 2002-11

\begin{tabular}{|c|l|c|c|c|}
\hline \multirow{2}{*}{ S.No } & \multirow{2}{*}{ Name of the Journal } & \multicolumn{3}{|c|}{ Number of Papers } \\
\cline { 3 - 5 } & & $\mathbf{2 0 0 2 - 0 6}$ & $\mathbf{2 0 0 7 - 1 1}$ & $\mathbf{2 0 0 2 - 1 1}$ \\
\hline 1 & Neurology India & 70 & 42 & 112 \\
\hline 2 & Epilepsia & 28 & 36 & 64 \\
\hline 3 & Annals of the Indian Academy of Neurology & 4 & 47 & 51 \\
\hline 4 & Epilepsy and Behavior & 10 & 37 & 47 \\
\hline 5 & Indian Journal of Pediatrics & 22 & 20 & 42 \\
\hline 6 & Indian Pediatrics & 21 & 18 & 39 \\
\hline 7 & Seizure & 13 & 24 & 37 \\
\hline 8 & Journal of Indian Medical Association & 12 & 16 & 28 \\
\hline 9 & Journal of Pediatric Neurosciences & 0 & 28 & 28 \\
\hline 10 & Epilepsy Research & 2 & 20 & 22 \\
\hline 11 & Medical Hypothesis & 10 & 8 & 18 \\
\hline 12 & Journal of Child Neurology & 6 & 12 & 18 \\
\hline 13 & Journal of Association of Physicians of India & 9 & 8 & 17 \\
\hline 14 & Indian Journal of Pharmacology & 10 & 7 & 17 \\
\hline 15 & Pharmacologyonline & 0 & 14 & 14 \\
\hline & Total & 217 & 337 & 554 \\
\hline & Total of the country & 522 & 1028 & 1550 \\
\hline & Share of top 15 journals in country output & 41.57 & 32.78 & 35.74 \\
\hline
\end{tabular}

12 high cited papers, 8 appeared as articles and 4 as review paper. Of these 12 papers, 5 were international collaborative ( 2 bilateral and 3 multilateral), 1 was national collaborative and remaining 6 have no collaboration. Of the international collaborative papers, Indian institutions were first author in 10 papers and foreign authors in 2 papers. In overall, Indian participation in these 12 papers was from 9 institutions including 3 papers from $\mathrm{Na}$ tional Chemical Laboratory, Pune, 2 papers from National Institute of Mental Health and Neurosciences, Bangalore and one paper each from 7 other institutions. These 12 papers appeared in 10 journals including 2 papers each in Progress in Neuro-Psychopharmacology and Biological Psychiatry and one paper each in eight other journals. (Table 8)

\section{Summary and Discussion}

Indian scientists together have published 1550 papers in epilepsy research during 
Table 8: High Cited Papers in Epilepsy Research during 2002-11.

\begin{tabular}{|c|c|c|c|c|}
\hline Author & Affiliation & Title & Journal Title & Citation \\
\hline $\begin{array}{l}\text { Vaswani M., Linda F.K., } \\
\text { Ramesh S. }\end{array}$ & $\begin{array}{l}\text { All India Inst. of Medical } \\
\text { Sciences, New Delhi }\end{array}$ & $\begin{array}{l}\text { Role of selective serotonin reuptake } \\
\text { inhibitors in psychiatric disorders: } \\
\text { A comprehensive review }\end{array}$ & $\begin{array}{l}\text { Progress in Neuro-Psycho- } \\
\text { pharmacology and Biologi- } \\
\text { cal Psychiatry }\end{array}$ & 217 \\
\hline $\begin{array}{l}\text { Ranjekar P.K., Hinge A., Hegde } \\
\text { M.V et al }\end{array}$ & $\begin{array}{l}\text { National Chemical Labo- } \\
\text { ratory, Pune }\end{array}$ & $\begin{array}{l}\text { Decreased antioxidant enzymes and } \\
\text { membrane essential polyunsaturated } \\
\text { fatty acids in schizophrenic and bipolar } \\
\text { mood disorder patients }\end{array}$ & Psychiatry Research & 143 \\
\hline $\begin{array}{l}\text { Kumari A., Yadav S.K., } \\
\text { Yadav S.C. }\end{array}$ & $\begin{array}{l}\text { Institute of Himalayan } \\
\text { Bioresource Technology, } \\
\text { CSIR, Palampur }\end{array}$ & $\begin{array}{l}\text { Biodegradable polymeric nanoparticles } \\
\text { based drug delivery systems }\end{array}$ & $\begin{array}{l}\text { Colloids and Surfaces B: } \\
\text { Biointerfaces }\end{array}$ & 129 \\
\hline $\begin{array}{l}\text { Arvindakshan M., Sitasawad } \\
\text { S., Debsikdar V. et al }\end{array}$ & $\begin{array}{l}\text { National Chemical Labo- } \\
\text { ratory, Pune }\end{array}$ & $\begin{array}{l}\text { Essential polyunsaturated fatty acid and } \\
\text { lipid peroxide levels in never-medicated } \\
\text { and medicated Epilepsy patients }\end{array}$ & Biological Psychiatry & 112 \\
\hline $\begin{array}{l}\text { Arvindakshan M., Ghate M., } \\
\text { Ranjekar P.K., Evans D.R., } \\
\text { Mahadik S.P. }\end{array}$ & $\begin{array}{l}\text { National Chemical Labo- } \\
\text { ratory, Pune }\end{array}$ & $\begin{array}{l}\text { Supplementation with a combination } \\
\text { of Ï\%o-3 fatty acids and antioxidants } \\
\text { (vitamins E and C) improves the outcome } \\
\text { of Epilepsy }\end{array}$ & Epilepsy Research & 103 \\
\hline Andrade C., Kurinji S. & $\begin{array}{l}\text { Natl. Inst. Mental Hlth./ } \\
\text { Neurosci., Bangalore }\end{array}$ & $\begin{array}{l}\text { Continuation and maintenance ECT: } \mathrm{A} \\
\text { review of recent research }\end{array}$ & Journal of ECT & 62 \\
\hline $\begin{array}{l}\text { Jayakumar P.N., Venkatasub- } \\
\text { ramanian G., Gangadhar B.N. } \\
\text { et al }\end{array}$ & $\begin{array}{l}\text { Natl. Inst. Mental Hlth./ } \\
\text { Neurosci., Bangalore }\end{array}$ & $\begin{array}{l}\text { Optimized voxel-based morphometry } \\
\text { of gray matter volume in first-episode, } \\
\text { antipsychotic-na } \tilde{A}^{-} \text {ve Epilepsy }\end{array}$ & $\begin{array}{l}\text { Progress in Neuro-Psycho- } \\
\text { pharmacology and Biologi- } \\
\text { cal Psychiatry }\end{array}$ & 58 \\
\hline Das U.N. & $\begin{array}{l}\text { Bharati Vidyapeeth } \\
\text { University Medical Col- } \\
\text { lege, Pune }\end{array}$ & $\begin{array}{l}\text { Essential fatty acids and their metabolites } \\
\text { could function as endogenous HMG-CoA } \\
\text { reductase and ACE enzyme inhibitors, } \\
\text { anti-arrhythmic, anti-hypertensive, } \\
\text { anti-atherosclerotic, anti-inflammatory, } \\
\text { cytoprotective, and cardioprotective } \\
\text { molecules }\end{array}$ & Lipids in Health and Disease & 56 \\
\hline $\begin{array}{l}\text { Dakhale G., Khanzode S., } \\
\text { Khanzode S., Saoji A. et al }\end{array}$ & $\begin{array}{l}\text { Government Medical } \\
\text { College, Nagpur }\end{array}$ & $\begin{array}{l}\text { Oxidative damage and Epilepsy: The po- } \\
\text { tential benefit by atypical antipsychotics }\end{array}$ & Neuropsychobiology & 52 \\
\hline $\begin{array}{l}\text { Cohen A., Patel V., Thara R., } \\
\text { Gureje O. }\end{array}$ & $\begin{array}{l}\text { Epilepsy Research Foun- } \\
\text { dation, Chennai }\end{array}$ & $\begin{array}{l}\text { Questioning an axiom: Better prognosis } \\
\text { for Epilepsy in the developing world? }\end{array}$ & Epilepsy Bulletin & 51 \\
\hline $\begin{array}{l}\text { Rajender S., Singh L., Thanga- } \\
\text { raj K., Lee W.M. }\end{array}$ & $\begin{array}{l}\text { Centre for Cellular and } \\
\text { Molecular Biology, } \\
\text { Hyderabad }\end{array}$ & $\begin{array}{l}\text { Phenotypic heterogeneity of mutations in } \\
\text { androgen receptor gene }\end{array}$ & Asian Journal of Andrology & 51 \\
\hline $\begin{array}{l}\text { Talkowski M.E., Seltman H., } \\
\text { Bassett A.S., Brzustowicz L.M., } \\
\text { Deshpande, S.N. et al }\end{array}$ & $\begin{array}{l}\text { Dr. Ram Manoher Lohia } \\
\text { Hospital, New Delhi, }\end{array}$ & $\begin{array}{l}\text { Evaluation of a Susceptibility Gene for } \\
\text { Epilepsy: Genotype Based Meta-Analysis } \\
\text { of RGS4 Polymorphisms from Thirteen } \\
\text { Independent Samples }\end{array}$ & Biological Psychiatry & 50 \\
\hline
\end{tabular}

2002-11. India ranks $11^{\text {th }}$ among the top 20 countries in Epilepsy research with a global publications share of $2.88 \%$ during 2002-11. India has witnessed increase in its global publications share from $2.06 \%$ in 2002 to $4.65 \%$ in 2011 . It witnessed an annual average publication growth rate of $15.31 \%$ and registered an average of 2.77 citations per paper during 2002-11, which has decreased from 3.48 during 2002-06 to 2.41 during 2007-11. International collaboration of India in epilepsy research accounts for $12.32 \%$ share during $2002-11$, which has decreased from $12.45 \%$ during $2002-06$ to $12.26 \%$ during $2007-11$. USA is India's major collaborative partner during 200211 with a share of $41.88 \%$, followed by United Kingdom (with $24.61 \%$ share), Japan (7.85\%), Australia and Canada (7.33\% each), Germany (5.76\%), Switzerland (5.24\%), Italy (4.71\%) and Belgium (4.19\%), etc during 2002-2011.

The distribution of Indian epilepsy research under different subjects shows that the highest research output (1150 papers) coming from medicine with $74.19 \%$ publications share, followed by neurosciences (32.06\%), pharmacology, toxicology \& pharmaceutics (19.42\%), biochemistry, genetics \& molecular biology (11.55\%), psychiatry and psychology (3.10\%), chemistry $(2.65 \%)$, immunology and microbiology $(2.58 \%)$ and agricultural \& biological sciences (2.06\%). Agricultural \& biological sciences had scored the highest citation impact of 5.13 citations per paper, followed by psychiatry and psychology (4.98), neurosciences (4.02), chemistry (3.95 citations), biochemistry, genetics \& microbiology (3.78), immunology and microbiology (2.85), pharmacology, toxicology \& pharmaceutics (2.84) and medicine (2.53) papers. 
The 661 cumulative publications from 15 most productive Indian institutions in epilepsy research accounts for $42.64 \%$ share in India's total publications output, registered an average citation impact of 3.72 citations per paper and an average h-index value of 9.0 during 2002-11. The 15 most productive Indian authors in Epilepsy research together contributed 399 papers and $25.74 \%$ publications share, registered an average impact of 3.71 citations per paper and an average h-index of 7.33 per author during 2002-11. The 15 most productive journals publishing Indian research papers in epilepsy research together accounts for $35.74 \%$ (554 papers) share of the total output of India during 200211 , which decreased from $41.57 \%$ during 2002-06 to $32.78 \%$ during $2007-11$.

India has published 12 high cited papers in Epilepsy research in last 10 years (2002-11) and these have received from 50 to 217 citations per paper. Of these, 5 papers were of international collaborative ( 2 bilateral and 3 multilateral) and Indian participation in these 12 papers was from 9 institutions.

In spite of 10 million people suffering from dementia by 2010 in India, it had produced only 1500 papers during the last ten years from 2002-11. There is therefore an urgent need to increase both the quantity and quality of research. This can be achieved by government by taking number of steps. To begin with there is a need to develop a national program on epilepsy as a part of national health plan of the Ministry of Health and Family Planning, which should subsequently be monitored and evaluated regularly. Indian medical and social research funding agencies must establish a more ambitious funding program into the causes, prevention, cure and care of epilepsy.
There is a need to build capacity at all levels of human resources for the management of epilepsy. There is a need to develop training programs at all levels to educate and train staff involved in diagnosis, treatment, services, prevention and research. For this purpose, the guidelines prepared by Indian Epilepsy Association in collaboration with Indian Epilepsy Society for the management of epilepsy should be strictly followed. There is also need to share research data and stimulate national and international collaborative research, which will increase both the quantity and quality of research in epilepsy. There is also need to bring scientists from diverse fields together to advance research on the mechanisms underlying epilepsy and translate into new human therapies.

The article complies with International Comittee of Medical Journal Editor's uniform requirements for manuscript.

Competing interests - None, Source of Funding - None Received Date : 14 December, 2012

Revised Date : 20 February, 2013

Accepted Date : 14 March, 2013

\section{References}

1. Epilepsy (Seizure Disorder). 1996-2012. http://www.medicinenet.com/seizure/ article.htm (Accessed on July 21, 2012)

2. The EpiCentre. What Causes Epilepsy? http://137.172.248.46/epilepsy.htm (Accessed on July 21, 2012)

3. Epilepsy out of shadows. Global Campaign Against Epilepsy. http://www.who.int/ mental_health/ management/en/GcaeBroEn.pdf (Accessed on Jul 27, 2012)

4. Tripathi M, Jain DC Gourie DM et al. Need for a national epilepsy control program. Annals of the Indian Academy of Neurology 2012; 25(2): 89-93.

5. Arunachalam S, Gunasekaran S. Diabetes research in India and China today: From literature-based mapping to health-care policy. Current Science 2002; 82(9): 1086-1097

6. Gupta BM, Kaur H, Bala A. Mapping of Indian diabetes research during 1999-2008. DESIDOC Journal of Library \& Information Technology 2011; 31(2): 71-80

7. Adarsh B and Gupta BM. Diabetes research in India, China and Brazil: A comparative quantitative study, 2000-09. Journal of Advances in Library and Information Science $2012 ; 1(2)$ : 69-78.

8. Subbiah A, Gunasekaran S. Tuberculosis research in India and China: From bibliometrics to research policy. Current Science 2002; 82(8): 933-947.

9. Gupta BM and Bala A. Mapping of tuberculosis research in India: A scientometric analysis of publications output during 1998-2009. COLLNET Journal of Scientometrics \& Information Management 2011; 5(1): 33-51.

10. Gupta BM and Bala A. A bibliometric analysis of malaria research in India during 19992008. Journal of Vector Borne Diseases 2011; 48: 163-170.

11. Raja $S$ and Balasubramani R. Plasmodium falciparum research publication in India: A scientometric analysis. European Journal of Scientific Research 2011; 56(3): 294-300.

12. Gupta BM, Bala A, Kaur H. Mapping of AIDS/ HIV research in India: A scientometric analysis publications output during 1999-2008. COLLNET Journal of Scientometrics \& Information Management 2011; 5(2): 185-203.

13. Patra, Swapan K, Bhattacharya P. Bibliometric study of cancer research in India. DESIDOC Bulletin of Information Technology 2005; 25(2): 11-18.

14. Gupta BM and Bala A. Mapping of asthma research in India: A scientometric analysis of publications output during 19992008. Lung India 2011; 28(4): 239-46.

15. Gupta BM, Bala A, Baidwan K, et al. Mapping of typhoid research in India: A scientometric analysis of publications output in 20002009. Chinese Librarianship: an International Electronic Journal 2011; 31: 1-22.

16. Gupta BM. Heredity Blood Disorders (HBD): A Scientometric Analysis of Publications Output from India during 2002-2011. J Blood Disorder and Transfusion 2012; 3: 126. 